\title{
Gas Exchange and Growth of Medicinal Plant Subjected to Salinity and Application of Biofertilizers
}

\author{
Sergiane Beatriz da Silva Mesquitaㅁ, José Adriano da Silva², Rafael Santiago da Costa1, \\ Móises Wilkson Nunes dos Santos ${ }^{1}$, Claudivan Feitosa de Lacerda ${ }^{2}$, Aiala Vieira Amorim1, \\ Antonio Marcos Esmeraldo Bezerra ${ }^{2}$ \\ ${ }^{1}$ Universidade da Integração Internacional da Lusofonia Afro-Brasileira (UNILAB), Campus da Liberdade, \\ Redenção, Brasil \\ ${ }^{2}$ Universidade Federal do Ceará (UFC), Fortaleza, Brasil \\ Email: aialaamorim@unilab.edu.br
}

Received 9 May 2014; revised 19 June 2014; accepted 18 July 2014

Copyright (C) 2014 by authors and Scientific Research Publishing Inc.

This work is licensed under the Creative Commons Attribution International License (CC BY). http://creativecommons.org/licenses/by/4.0/

(c) (i) Open Access

\section{Abstract}

The objective of this study was to evaluate the use of biofertilizers and saline waters on gas exchange and growth of medicinal plant Plectrantus amboinicus. The experiment was conducted in the period February to May 2013 in a greenhouse. The experimental design was completely randomized in a $2 \times 4$ factorial arrangement, with two levels of salinity of irrigation water (ECw: 0.7 and $3.1 \mathrm{dS} \mathrm{m}^{-1}$ ) and four levels of bovine liquid biofertilizer applied to the soil, corresponding to $0 \%, 10 \%, 20 \%$ and $30 \%$ of the soil volume, with five replications. The experiment lasted 60 days, counted from the beginning of the treatments. The stomatal conductance (gs), photosynthesis (A), transpiration (E), intrinsic water use efficiency (WUEi) were performed at the end of the experiment, and the height, number of leaves and stem diameter at the beginning and at the end. Generally plants subjected to salinity of irrigation water of $3.1 \mathrm{dS} \mathrm{m}^{-1}$ had the lowest values of gas exchange. Moreover, the application of biofertilizers and the interaction between this and salinity did not affect any growth variable studied except the stem length in the final phase which was influenced by salinity at $5 \%$ probability by $F$ test. The average values of this variable were $57.22 \mathrm{~cm}$ and $69.65 \mathrm{~cm}$ when applied water ECw: 0.7 to $3.1 \mathrm{dS} \mathrm{m}^{-1}$, respectively. The application of biofertilizers can reduce the effect of salinity on the final plant height of Plectrantus amboinicus, especially when the plants were fertilized with a dose of $20 \%$ of biofertilizers.

\section{Keywords}

Medicinal Plants, Salt Stress, Fertilizers

How to cite this paper: Mesquita, S.B.S., Silva, J.A., Costa, R.S., Santos, M.W.N., Lacerda, C.F., Amorim, A.V. and Bezerra A.M.E. (2014) Gas Exchange and Growth of Medicinal Plant Subjected to Salinity and Application of Biofertilizers. American Journal of Plant Sciences, 5, 2520-2527. http://dx.doi.org/10.4236/ajps.2014.516266 


\section{Introduction}

High concentration of salts is an important characteristic of the soils of semi-arid and arid regions of the world and is a continuing threat to crop production [1]-[3]. It has been estimated that high soil salinity brought about by mismanaged irrigation systems undermines the yield productivity of at least one-third of the world's irrigation lands [4]. Recent trends and future projections suggest that the need to produce more food and fiber for the expanding population will lead to an increase in the use of salt-prone water and land resources for crop-production systems, and this will be met by using salt-tolerant crops or halophytes [5] [6]. Biosaline agriculture is now becoming a reliable strategy for using saline environment [7].

As [8] there are several effects caused by salt stress in plants: the osmotic effect, the toxic effect of mineral elements (chlorides, boron, sodium) and the indirect effects, which occur when high concentrations of sodium or other cations in solution interfere with the physical condition of the soil or the availability of certain elements, affecting the growth and development of plants indirectly. The excess salts from irrigation water cause a reduction in photosynthetic rates, stomatal conductance and transpiration of plants. In addition to the gas exchange variables [9] found declines in chlorophyll levels, which result from imbalances in the physiological and biochemical activities promoted by the content of salts, above the limit tolerated by crops. However, saline soils can be utilized by growing salt tolerant crops. For example, A. majus is a potential medicinal crop, it could be grown on salt-affected lands if it possesses high degree of salt tolerance [10].

One of the alternatives that can minimize the deleterious effects of salinity and other adverse effects of the environment is the use of organic substances. The organic material functions as an organic soil amendment, since it can reduce the exchangeable sodium percentage (ESP) due to the release of $\mathrm{CO}_{2}$ and the production of organic acids during their decomposition, increase water retention and acts as a source of calcium and magnesium rather than the sodium [11]. An example of this was observed by [12], to detect the mitigating action of bovine biofertilizer in plants of paluma guava (Psidium guajava) subjected to salinity of irrigation water. However, little is known about the use of biofertilizers on medicinal plants.

Of the potential medicinal plants being cultivated these days, Plectranthus amboinicus (Lour) Spreng, belonging to family Lamiacea, is a traditional medicinal herb which is also known as Karpuravalli, Omavalli in Tamil, Patta ajavayin, Patharcur in Hindi, Country borage in English [13]. This species is a large succulent aromatic perennial herb which together with Plectranthus barbatus have the widest geographical range of family Lamiacea occurring beyond Africa and Asia continents into the Americas [13]. The species Plectranthus amboinicus has a variety of properties. The leaves have been used in malarial fever, hepatopathy, renal and vesical calculi, cough, chronic asthma, hiccough, bronchitis, anthelmintic, colic and convulsions [13], are often rubbed into the hair and body after bathing [14], are mixed with sugar and used as an intoxicant [15], used as insect repellants [16], in food stuffings [17], for flavouring and marinating beef and chicken [18]-[22], to mask odor of strong smells associated with goat, fish and shellfish [14]. Also this plant is offered to the spirits when a house is being built [14].

Based on the foregoing, the aim of the present study was to evaluate the use of biofertilizers and salt on gas exchange and development of medicinal plants of the Plectranthus amboinicus.

\section{Materials and Methods}

\subsection{The Experiment Site}

The experiment was conducted in a greenhouse owned by the Center for Teaching and Research in Urban Agriculture (NEPAU), Federal University of Ceará-UFC, located in Fortaleza-CE, latitude $3^{\circ} 44^{\prime}$ S, longitude $38^{\circ} 33^{\prime}$ W, in altitude of $20 \mathrm{~m}$ during the period from February to May 2013. The climate is Aw (rainy tropical) according to Köeppen classification. The average values of temperature and relative humidity inside the greenhouse were $30.02^{\circ} \mathrm{C}$ and $79.5 \%$, respectively.

\subsection{Plant Material}

For this study we used the species (Plectranthus amboinicus (Lour) Spreng). The seedlings of this species were produced by vegetative propagation (cuttings) and placed in polyethylene bags containing a mixture of substrate as aloof + earthworm humus, in a 2:1 ratio, where they will remain for a period of 30 days. Subsequently, seedlings were selected for uniformity, height and diameter of the pile, and transplanted to plastic pots with a capaci- 
ty of $7.5 \mathrm{~L}$, containing the same substrate used for the training of seedling. The characteristics of the substrate were $\mathrm{pH}$ in $\mathrm{H}_{2} \mathrm{O}(1: 2.5)=6.7 ; \mathrm{Ca}^{2+}=5.1 \mathrm{cmol}_{\mathrm{C}} / \mathrm{dm}^{3} ; \mathrm{Mg}^{2+}=3.6 \mathrm{cmol}_{\mathrm{C}} / \mathrm{dm}^{3} ; \mathrm{Na}=1.39 \mathrm{cmol}_{\mathrm{c}} / \mathrm{dm}^{3} ; \mathrm{K}^{+}=2.15$ $\mathrm{cmol}_{\mathrm{C}} / \mathrm{dm}^{3} ; \mathrm{SB}=12.25 \mathrm{cmol}_{\mathrm{C}} / \mathrm{dm}^{3} ; \mathrm{H}+\mathrm{Al}=1.65 \mathrm{cmol}_{\mathrm{C}} / \mathrm{dm}^{3} ; \mathrm{Al}^{3+}=0.00 ; \mathrm{V} \%=88.13 ; \mathrm{P}=493.84 \mathrm{mg} / \mathrm{dm}^{3} ; \mathrm{C}=$ $1.43 \%$; M.O. $=2.46 \%$.

Before application of treatments the seedlings were kept for 10 days in greenhouse with $50 \%$ brightness, in order to restore the stress suffered at transplanting and started to issue new roots and leaves. The experiment lasted 60 days, counted from the beginning of the application of the treatments, the plants were kept in a greenhouse with $50 \%$ brightness.

\subsection{Experimental Design and Treatments}

The experiment was conducted according to a completely randomized design in a $2 \times 4$ factorial arrangement, with two levels of salinity of irrigation water ECw: 0.7 and $3.1 \mathrm{dS} \mathrm{m}^{-1}$ and four levels of biofertilizers applied liquid bovine to the ground, corresponding to $(0,10,20$ and 30\%) of the volume of the soil, with five replications.

Water sources used were from two wells, one with electrical conductivity of $0.7 \mathrm{dS} \mathrm{m}^{-1}$ and the other with ECw of $3.1 \mathrm{dS} \mathrm{m}^{-1}$. Irrigation was performed every two days and the amount of water applied was estimated with the objective of soil to reach field capacity, adding a leaching fraction of 0.15 for the water percole the bottom of the vessels in order to avoid excessive accumulation of salts. The application of water was manual, localized way to prevent direct effects on the leaves.

The biofertilizer was prepared by anaerobic fermentation of manure in black plastic pots containing fresh water at a ratio of $50 \%($ volume/volume $=\mathrm{v} / \mathrm{v})$ for a period of thirty to sixty days. The results of three chemical analyzes of biofertilizers performed throughout the experiment are shown in Table 1.

\subsection{Variables Evaluated}

At the end of the experiment were performed on fully expanded leaf measurements of stomatal conductance (gs), net photosynthetic rate (A) and transpiration rate (E), using an infrared gas analyzer (IRGA) model Li-6400XT (Licor, USA). The measurements were conducted between 08:00 and 12:00h under natural conditions of air temperature, and $\mathrm{CO}_{2}$ concentration, and photosynthetic active radiation of $1600 \mu \mathrm{mol} \mathrm{m} \mathrm{s}^{-2}$. From the data obtained was estimated intrinsic water use efficiency (A/gs). During the measurements of gas exchange is also estimated the IRC, using laptop SPAD 502 (Minolta).

Height was determined with the aid of a graduated ruler, the number of leaves was determined by manual counting and stem diameter using a caliper.

\subsection{Statistical Analyzes}

The results were statistically analyzed using the "ASSISTAT 7.6 BETA" program. The data of analyzed variables were subjected to analysis of variance and subsequently as significant by the F test, submitted to Tukey's

Table 1. Chemical attributes of biofertilizer used in the experiment.

\begin{tabular}{|c|c|c|c|c|}
\hline Elements & 1st Application & 2nd Application & 3rd Application & units \\
\hline $\mathrm{N}$ & 0.7 & 1.1 & 1.0 & $\mathrm{~g} \cdot \mathrm{kg}^{-1}$ \\
\hline $\mathrm{P}$ & 0.1 & 0.3 & 0.3 & $\mathrm{~g} \cdot \mathrm{kg}^{-1}$ \\
\hline $\mathrm{P}_{2} \mathrm{O}_{5}$ & 0.2 & 0.7 & 0.7 & $\mathrm{~g} \cdot \mathrm{kg}^{-1}$ \\
\hline K & 1.5 & 1.7 & 1.5 & $\mathrm{~g} \cdot \mathrm{kg}^{-1}$ \\
\hline $\mathrm{K}_{2} \mathrm{O}$ & 1.8 & 2.1 & 1.8 & $\mathrm{~g} \cdot \mathrm{kg}^{-1}$ \\
\hline $\mathrm{Ca}$ & 2.0 & 1.6 & 1.5 & $\mathrm{~g} \cdot \mathrm{kg}^{-1}$ \\
\hline $\mathrm{Mg}$ & 0,5 & 0.8 & 0.6 & $\mathrm{~g} \cdot \mathrm{kg}^{-1}$ \\
\hline $\mathrm{Fe}$ & 28.1 & 69.8 & 69.1 & $\mathrm{mg} \cdot \mathrm{kg}^{-1}$ \\
\hline $\mathrm{Cu}$ & 0.6 & 0.3 & 0.9 & $\mathrm{mg} \cdot \mathrm{kg}^{-1}$ \\
\hline $\mathrm{Zn}$ & 6.7 & 17.9 & 20.4 & $\mathrm{mg} \cdot \mathrm{kg}^{-1}$ \\
\hline $\mathrm{Mn}$ & 5.3 & 12.1 & 14.0 & $\mathrm{mg} \cdot \mathrm{kg}^{-1}$ \\
\hline
\end{tabular}


$\mathrm{p}<0.05$. In regression analysis, the equations that best fit the data were selected based on the significance of the regression coefficients at $1 \%$ and $5 \%$ probability by $\mathrm{F}$ test and greater coefficient of determination.

\section{Results}

\subsection{Gas Exchange}

In the analysis of variance shown in Table 2, it can be observed that with the exception of chlorophyll content all gas exchange variables were influenced by salinity. The biofertilizer and biofertilizer/salinity interaction did not affect the chlorophyll content, and intrinsic water use efficiency (WUEi), while stomatal conductance (gs), photosynthesis (A) and transpiration (E), were influenced by these two factors, the significance level of $1 \%$ probability by $\mathrm{F}$ test.

Observe in Figure 1 that generally plants subjected to salinity of irrigation water from $3.1 \mathrm{dS} \mathrm{m}^{-1}$ had the lowest values of gas exchange. However, it appears that plants irrigated with irrigation conductivity of $0.7 \mathrm{dS} \mathrm{m}^{-1}$ water suffered an abrupt decrease when applied 30\% of biofertilizer, which did not occur in plants under higher salinity.

\subsection{Growth}

In the analysis of variance presented in Table 3, it can be observed that no variable was influenced by salinity, biofertilizer or the interaction between these two factors, with exception of the height at the end of the experiment which was influenced by salinity at a significance level of $1 \%$ probability by $\mathrm{F}$ test. This shows the impossibility of detecting the benefit of the use of biofertilizers in alleviating the effect of salinity on plants of the Plectranthus amboinicus, at least at the levels used in the present study.

It is observed in Figure 2 that the plants Plectrantus amboinicus collected at the end of the experiment, independent of the electrical conductivity of the irrigation water, had lower height values when doses were fertilized with $30 \%$ of biofertilizers. The highest value for this variable was observed in plants grown with $3.1 \mathrm{ECw}$ water and fertilized with $20 \%$ of biofertilizers.

\section{Discussion}

Similar to that observed in this study, other authors have observed that salinity reduces gs, $A$ and $E$ in most plant species [23]-[25]. Salt-induced reduction of $A$ can be caused by stomatal limitation with stomatal closure [26] [27],

Table 2. Values summarized the analysis of variance for stomatal conductance (gs), rates of net photosynthesis (A), transpiration (E), chlorophyll, intrinsic water use efficiency (WUEi) in plants of Plectrantus amboinicus under different levels of biofertilizers and water salinity irrigation.

\begin{tabular}{|c|c|c|c|c|c|c|}
\hline \multirow{2}{*}{$\begin{array}{c}\text { Sources of } \\
\text { variation }\end{array}$} & \multirow{2}{*}{ DL } & \multicolumn{5}{|c|}{ Medium Square } \\
\hline & & gs & A & E & Chlorophyll & WUEi \\
\hline Salinity (A) & 1 & $0.11^{* *}$ & $129.70^{* *}$ & $55.13^{* *}$ & $0.11^{\mathrm{ns}}$ & $4532.85^{* *}$ \\
\hline Biofertilizer (B) & 3 & $0.01^{* *}$ & $34.76^{* *}$ & $8.27^{* *}$ & $2.20^{\mathrm{ns}}$ & $46.17^{\text {ns }}$ \\
\hline Int. $(\mathrm{A} \times \mathrm{B})$ & 3 & $0.02^{* *}$ & $45.90^{* *}$ & $13.44^{* *}$ & $10.75^{\mathrm{ns}}$ & $207.30^{\mathrm{ns}}$ \\
\hline Treatments & 7 & $0.03^{* *}$ & $53.10^{* *}$ & $17.18^{* * *}$ & $5.56^{\mathrm{ns}}$ & $756.18^{* *}$ \\
\hline Residue & 32 & 0.0027 & 4.64 & 1.48 & 16.32 & 210.16 \\
\hline $\mathrm{CV} \%$ & - & 46.40 & 37.20 & 36.11 & 13.88 & 25.58 \\
\hline Salinity $0.7 \mathrm{dS} \mathrm{m}^{-1}$ & - & $0.16 \mathrm{a}$ & 7.59a & $4.55 a$ & $29.16 a$ & $46.03 \mathrm{~b}$ \\
\hline Salinity $3.1 \mathrm{dS} \mathrm{m}^{-1}$ & - & $0.06 \mathrm{~b}$ & $3.99 b$ & $2.20 \mathrm{~b}$ & $29.05 a$ & $67.32 \mathrm{a}$ \\
\hline Biofertilizer 0\% & - & 0.13a & $7.04 \mathrm{a}$ & $3.76 a$ & $29.27 a$ & $59.35 a$ \\
\hline Biofertilizer 10\% & - & $0.14 \mathrm{a}$ & $6.96 a$ & $4.06 \mathrm{a}$ & $29.57 a$ & $56.64 a$ \\
\hline Biofertilizer 20\% & - & $0.12 \mathrm{a}$ & $6.07 a$ & $3.65 a$ & $28.46 a$ & $56.62 a$ \\
\hline Biofertilizer 30\% & - & $0.05 b$ & $3.07 b$ & $2.04 \mathrm{~b}$ & 29.13a & $54.09 \mathrm{a}$ \\
\hline
\end{tabular}

${ }^{* *},{ }^{*}$ and ns — significant at $1 \%$ and $5 \%$ of probability and not significant by F test, respectively. CV-coefficient of variation in percent. DF-Degrees of liberty. Means followed by the same lower case letter in columns do not differ by Tukey test $(\mathrm{p}<0.01$ and $\mathrm{p}<0.05)$. 


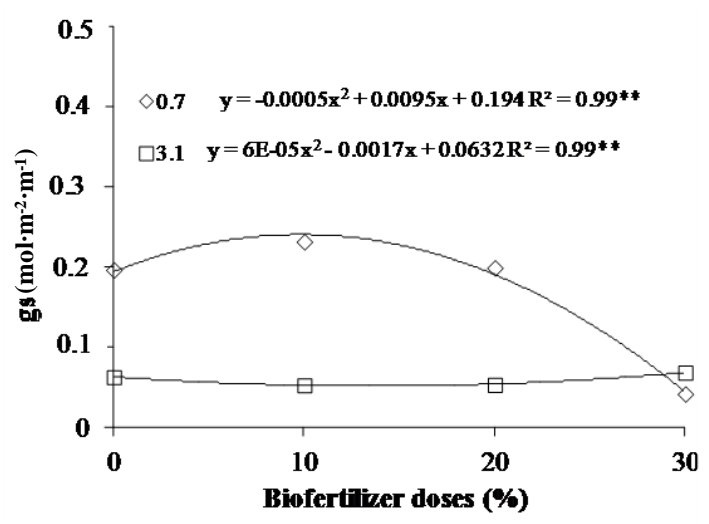

(a)

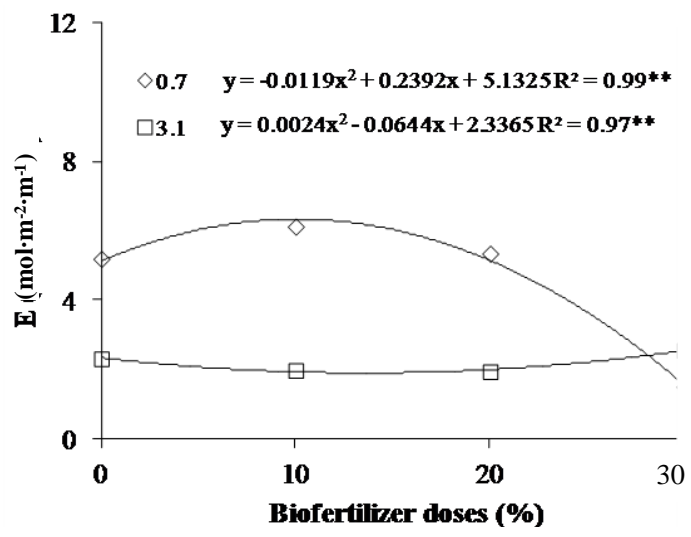

(c)

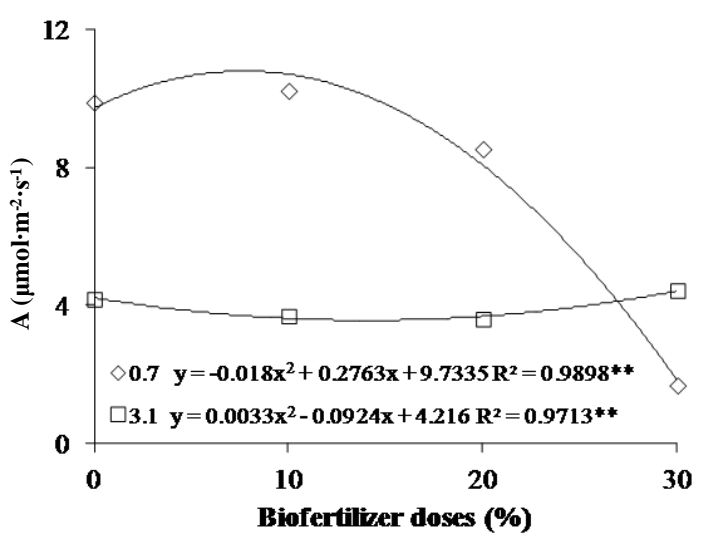

(b)

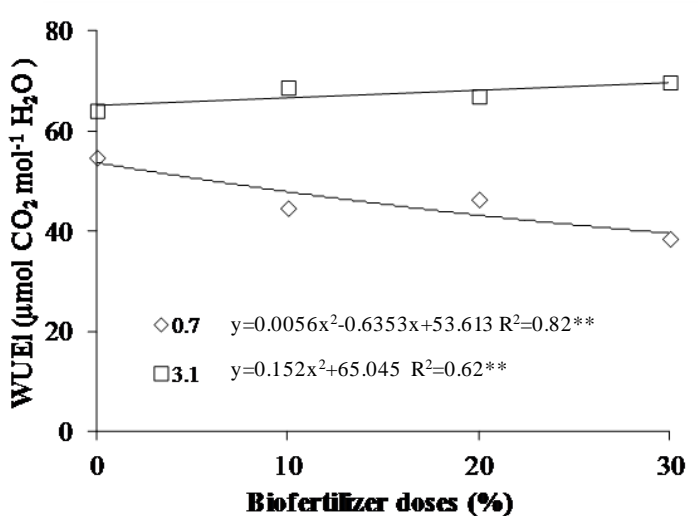

(d)

Figure 1. Stomatal conductance (gs), rates of net photosynthesis (A), transpiration rate (E), intrinsic water use efficiency (WUEi) in plants of Plectrantus amboinicus under two levels of irrigation water salinity (ECw: 0.7 and $3.1 \mathrm{dS} \mathrm{m}^{-1}$ ) and four doses of biofertilizer.

Table 3. Values summarized analysis of variance for the height, number of leaves and stem diameter of plants of Plectrantus amboinicus under different levels of biofertilizers and salinity of irrigation water.

\begin{tabular}{|c|c|c|c|c|c|c|c|}
\hline \multirow{3}{*}{$\begin{array}{c}\text { Sources of } \\
\text { variation }\end{array}$} & \multirow{3}{*}{ DL } & \multicolumn{6}{|c|}{ Medium Square } \\
\hline & & \multicolumn{2}{|c|}{ Height } & \multicolumn{2}{|c|}{ Number of leaves } & \multicolumn{2}{|c|}{ Stem diameter } \\
\hline & & initial & end & initial & end & initial & end \\
\hline Salinity (A) & 1 & $2.50^{\mathrm{ns}}$ & $1543.80^{*}$ & $0.02^{\mathrm{ns}}$ & $90.00^{\mathrm{ns}}$ & $0.12^{\mathrm{ns}}$ & $1.52^{\mathrm{ns}}$ \\
\hline Biofertilizer (B) & 3 & $11.84^{\mathrm{ns}}$ & $251.02^{\mathrm{ns}}$ & $1.49^{\mathrm{ns}}$ & $35.00^{\mathrm{ns}}$ & $0.48^{\mathrm{ns}}$ & $0.63^{\text {ns }}$ \\
\hline Int. $(\mathrm{A} \times \mathrm{B})$ & 3 & $11.61^{\mathrm{ns}}$ & $166.83^{\text {ns }}$ & $1.49^{\text {ns }}$ & $490.20^{\mathrm{ns}}$ & $1.19^{\text {ns }}$ & $1.20^{\mathrm{ns}}$ \\
\hline Treatments & 7 & $10.41^{\mathrm{ns}}$ & $399.62^{\mathrm{ns}}$ & $1.28^{\mathrm{ns}}$ & $237.94^{\mathrm{ns}}$ & $0.73^{\mathrm{ns}}$ & $1.00^{\mathrm{ns}}$ \\
\hline Residue & 32 & 14.51 & 212.03 & 2.07 & 245.00 & 0.80 & 0.82 \\
\hline CV\% & - & 20.24 & 22.95 & 22.60 & 19.49 & 13.61 & 11.62 \\
\hline Salinity $0.7 \mathrm{dS} \mathrm{m}^{-1}$ & - & $18.57 \mathrm{a}$ & $57.22 \mathrm{~b}$ & $6.40 \mathrm{a}$ & $81.90 \mathrm{a}$ & $6.64 a$ & 7.61a \\
\hline Salinity $3.1 \mathrm{dS} \mathrm{m}^{-1}$ & - & $19.07 a$ & $69.65 a$ & $6.35 \mathrm{a}$ & $78.90 \mathrm{a}$ & $6.53 a$ & $8.00 \mathrm{a}$ \\
\hline Biofertilizer 0\% & - & $19.85 a$ & $60.85 a$ & $6.10 \mathrm{a}$ & $82.20 \mathrm{a}$ & $6.61 \mathrm{a}$ & $7.44 a$ \\
\hline Biofertilizer 10\% & - & $17.55 a$ & $63.00 \mathrm{a}$ & $6.00 \mathrm{a}$ & 78.50a & 6.61a & $7.94 a$ \\
\hline Biofertilizer 20\% & - & 18.30a & 70.60a & $6.80 \mathrm{a}$ & $81.80 \mathrm{a}$ & 6.83a & $7.87 a$ \\
\hline Biofertilizer 30\% & - & 19.60a & 59.30a & 6.60a & 79.10a & $6.29 a$ & 7.99a \\
\hline
\end{tabular}

** * and ns — significant at $1 \%$ and $5 \%$ of probability and not significant by F test, respectively. CV—coefficient of variation in percent. DF-Degrees of liberty. Means followed by the same lower case letter in columns do not differ by Tukey test $(\mathrm{p}<0.01$ and $\mathrm{p}<0.05)$. 


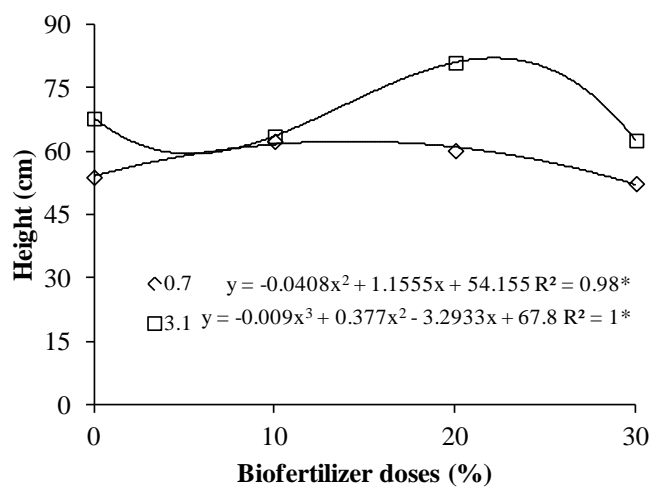

Figure 2. Plant height of Plectrantus amboinicus under two levels of salinity of irrigation water (ECw: 0.7 and $3.1 \mathrm{dS} \mathrm{m}^{-1}$ ) and four doses of biofertilizer.

nonstomatal limitation or both limitations with stomatal closure at low tissue salt concentration, and a disturbance of photosynthetic activity at high tissue salt content [28] [29]. However, some researchers not find any significant effect of salt stress on gas exchange in herbal A. majus [10], Hibiscus cannabinus [30], Hordeum vulgare [31], Trifolium repens [32], Triticum aestivum [33] [34], and Olea europea [35].

According [2], inhibition of growth in plants grown under salinity may be due to osmotic effects of salts, reducing the availability of water in the soil solution and/or the excess of ions absorbed by the plant metabolism leading to toxic effects, and this phase that clearly separates species and genotypes that differ in tolerance or sensitivity to salinity. However, in the present work to fertilizing with biofertilizer at least up to $20 \%$, seems to have alleviated the effect of salinity stress on plant height at the end of the experiment, whereas the values of this variable were higher when irrigated with saline water higher electrical conductivity.

Excess salts can alter the physiological and biochemical functions of plants, resulting in disturbances in water relations, changes in the absorption and use of essential plant nutrients, affecting their final growth and yield. However, according to [36], the intensity of salt stress is dependent on many factors, among them, the plant species, cultivar, developmental stage, saline medium composition, intensity and duration of stress, as well as the climatic conditions and irrigation management. This may explain in part the fact that salinity did not influence the studied plants.

Regarding the relationship beneficial for biofertilizer with salinity, some studies have shown that the use of biofertilizer in saline environments can partially mitigate the impact of salinity on the growth of plants [37]. The importance of the use of liquid biofertilizers, as simple or enriched microbial fermentation, is the quantitative elements in the diversity of chelated and made available for biological activity as an enzyme activator and plant metabolism nutrients.

\section{Conclusions}

The stomatal conductance, rates of net photosynthesis and transpiration showed lower values when the plants of Plectrantus amboinicus were irrigated with ECw: $3.1 \mathrm{dS} \mathrm{m}^{-1}$. However, it can be seen that the interaction of biofertilizers to $30 \%$ with saline water benefited gas exchange of these plants.

The application of biofertilizers can reduce the effect of salinity on the final plant height of Plectrantus amboinicus, especially when the plants were fertilized with a dose of $20 \%$ of biofertilizers. This positive effect can be associated with better nutrition of the plant.

\section{Acknowledgments}

The authors thank CAPES and INCTSal funding this research and Unilab the granting of a research grant.

\section{References}

[1] Ashraf, M. (2002) Salt Tolerance of Cotton: Some New Advances. Critical Reviews in Plant Sciences, 21, 1-30. http://dx.doi.org/10.1016/S0735-2689(02)80036-3 
[2] Munns, R. (2002) Comparative Physiology of Salt and Water Stress. Plant, Cell and Environment, 25, 239-250. http://dx.doi.org/10.1046/j.0016-8025.2001.00808.x

[3] Tester, M. and Davenport, R. (2003) $\mathrm{Na}^{+}$Tolerance and $\mathrm{Na}^{+}$Transport in Higher Plants. Annals of Botany, 91, 1-25. http://dx.doi.org/10.1093/aob/mcg058

[4] Reeve, R.C. and Fireman, M. (1967) Salt Problems in Relation to Irrigation. In: Hagan, R.M., Haise, H.R. and Edminster, T.W., Eds., Irrigation of Agricultural Lands, American Society of Agronomy, Madison, 988-1008.

[5] Khan, M.A., Ansari, R., Ali, H., Gul, B. and Nielsen, B.L. (2009) Panicum turgidum, a Potentially Sustainable Cattle Feed Alternative to Maize for Saline Areas. Agriculture, Ecosystems and Environment, 129, 542-546. http://dx.doi.org/10.1016/j.agee.2008.10.014

[6] Yensen, N.P. and Biel, K.Y. (2006) Soil Remediation via Salt-Conduction and the Hypotheses of Halosynthesis and photoprotection, Tasks for Vegetation Science Series 40. Ecophysiology of High Salinity Tolerant Plants, 313-344.

[7] Kafi, M., Asadi, H. and Ganjeali, A. (2010) Possible Utilization of High-Salinity Waters and Application of Low Amounts of Water for Production of the Halophyte Kochia scoparia as Alternative Fodder in Saline Agroecosystems. Agricultural Water Management, 97, 139-147. http://dx.doi.org/10.1016/j.agwat.2009.08.022

[8] Larcher, W. (2003) Physiological Plant Ecology: Ecophysiology and Stress Physiology of functional groups. 4th Edition, Springer, New York, 513. http://dx.doi.org/10.1007/978-3-662-05214-3

[9] Munns, R. and Tester, M. (2008) Mechanisms of Salinity Tolerance. Annual Reviews Plant Biology, 59, 651-681. http://dx.doi.org/10.1146/annurev.arplant.59.032607.092911

[10] Ashraf, M., Mukhtar, N., Rehman, S. and Rha, E.S. (2004) Salt-Induced Changes in Photosynthetic Activity and Growth in a Potential Medicinal Plant Bishop's Weed (Ammi majus L.), Photosynthetica, 42, 543-550. http://dx.doi.org/10.1007/S11099-005-0011-4

[11] Baalousha, M., Motelica-Heino, M. and Coustumer, P.L. (2006) Conformation and Size of Humic Substances: Effects of Major Cation Concentration and Type, pH, Salinity, and Residence Time. Colloids and Surfaces A: Physicochemical and Engineering Aspects, 272, 48-55. http://dx.doi.org/10.1016/j.colsurfa.2005.07.010

[12] Cavalcante, L.F., Vieira, M.S., Santos, A. F., Oliveira, W.M. and Nascimento, J.A.M. (2010) Água salina e esterco bovino líquido na formação de mudas de goiabeira cultivar paluma. Revista Brasileira de Fruticultura, 32, 251-261. http://dx.doi.org/10.1590/S0100-29452010005000037

[13] Kaliappan, N.D. and Viswanathan, P.K. (2008) Pharmacognostical Studies on the Leaves of Plectranthus amboinicus (Lour) Spreng. International Journal of Green Pharmacy, 2, 182-184. http://dx.doi.org/10.4103/0973-8258.42740

[14] Morton, J.F. (2010) Country Borage (Coleus amboinicus Lour.): A Potent Flavoring and Medicinal Plant. Journal of Herbs, Spices and Medicinal Plants, 1, 77-90. http://dx.doi.org/10.1300/J044v01n01_09

[15] Jain, S.K. and Lata, S. (1996) Amazonian Uses of Some Plants Growing in India. Indigenous Knowledge and Development Monitor, 4, 21-23.

[16] Omolo, M.O., Okinyo, D., Ndiege, I.O., Lwande, W. and Hassanali, A. (2004) Repellency of Essential Oils of Some Kenyan Plants against Anopheles gambiae. Phytochemisty, 65, 2797-2802. http://dx.doi.org/10.1016/j.phytochem.2004.08.035

[17] Purseglove, J.W. (1991) Tropical Crops. Dicotyledons. Longman Scientific and Technical. John Wiley and Sons, Inc. New York.

[18] Epling (1981) P. amboinicus (Lour.) Spreng. Herbarium Specimen held at K Collected from the Pacific (Epling 18080).

[19] Kuebel, K.R. and Tucker, A.O. (1988) Vietnamese Culinary Herbs in the United States. Economic Botany, 42, 413-419. http://dx.doi.org/10.1007/BF02860165

[20] Bodner, C.C. and Gereau, R.E. (1988) A Contribution to Bontoc Ethnobotany. Economic Botany, 42, $307-369$. http://dx.doi.org/10.1007/BF02860159

[21] Craig, Mayenda (1990) P. amboinicus (Lour.) Spreng. Herbarium Specimen held at K. Collected from the Pacific (Craig \& Mayenda 25).

[22] Brown, D. (1997) Grenada: Isle of Spices. Herbs, 22, 6-7.

[23] Gibberd, M.R., Turner, N.C. and Storey, R. (2002) Influence of Saline Irrigation on Growth, Ion Accumulation and Partitioning, and Leaf Gas Exchange of Carrot (Daucus carota L.) Annals of Botany, 90, 715-724. http://dx.doi.org/10.1093/aob/mcf253

[24] Tezara, W., Mitchell, V., Driscoll, S.P., Lawlor, D.W. (2002) Effects of Water Deficit and Its Interaction with $\mathrm{CO}_{2}$ Supply on the Biochemistry and Physiology of Photosynthesis in Sunflower. Journal of Experimental Botany, 53, 1781-1791. http://dx.doi.org/10.1093/jxb/erf021 
[25] Ashraf, M. and Shahbaz, M. (2003) Assessment of Genotypic Variation in Salt Tolerance of early CIMMYT Hexaploid Wheat Germplasm Using Photosynthetic Capacity and Water Relations as Selection Criteria. Photosynthetica, 41, 273-280. http://dx.doi.org/10.1023/B:PHOT.0000011961.33120.b6

[26] Pascale, S.D. and Barbieri, G. (1995) Effect of Soil Salinity from Long-Term Irrigation with Saline-Sodic Water on Yield and Quality of Winter Vegetable Crops. Scientia Horticulturae, 64, 145-147. http://dx.doi.org/10.1016/0304-4238(95)00823-3

[27] Goldstein, G., Drake, D.R., Alpha, C., Melcher, P., Heraux, J. and Azocar, A. (1996) Growth and Photosynthetic Responses of Scaevola sericea, a Hawaiian Coastal Shrub, to Substrate Salinity and Salt Spray. International Journal of Plant Sciences, 157, 171-179. http://dx.doi.org/10.1086/297336

[28] Downton, W.J.S., Loveys, B.R. and Grant, W.J.R. (1990) Salinity Effects on the Stomatal Behaviour of Grapevine. New Phytologist, 116, 499-503. http://dx.doi.org/10.1111/j.1469-8137.1990.tb00535.x

[29] Yeo, A.R., Lee, K.S., Izard, P., Boursier, P.J. and Flowers, T.J. (1991) Short and Long Term Effects of Salinity on Leaf Growth in Rice (Oryza sativa L.). Journal of Experimental Botany, 42, 881-889. http://dx.doi.org/10.1093/jxb/42.7.881

[30] Curtis, P.S. and Läuchli, A. (1986) The Role of Leaf Area Development and Photosynthetic Capacity in Determining Growth of Kenaf under Moderate Salt Stress. Australian Journal of Plant Physiology, 13, 553-565. http://dx.doi.org/10.1071/PP9860553

[31] Rawson, H.M., Richards, R.A. and Munns, R. (1988) An Examination of Selection Criteria for Salt Tolerance in Wheat, Barley and Triticale Genotypes. Australian Journal of Agricultural Research, 39, 759-772. http://dx.doi.org/10.1071/AR9880759

[32] Rogers, M.E. and Noble, C.L. (1992) Variation in Growth and Ion Accumulation between Two Selected Populations of Trifolium repens L. Differing in Salt Tolerance. Plant and Soil, 146, 131-136. http://dx.doi.org/10.1007/BF00012005

[33] Hawkins, H.J. and Lewis, O.A.M. (1993) Combination Effect of NaCl Salinity, Nitrogen form and Calcium Concentration on the Growth and Ionic Content and Gaseous Properties of Triticum aestivum L. cv. Gamtoos. New Phytologist, 124, 161-170. http://dx.doi.org/10.1111/j.1469-8137.1993.tb03806.x

[34] Ashraf, M. and O’Leary, J.W. (1996) Responses of Some Newly Evolved Salt-Tolerant Genotypes of Spring Wheat to Salt Stress: II. Water Relations and Gas Exchange. Acta Botanica Neerlandica, 45, 29-39. http://dx.doi.org/10.1111/j.1438-8677.1996.tb00493.x

[35] Loreto, F., Centritto, M. and Chartzoulakis, K. (2003) Photosynthetic Limitations in Olive Cultivars with Different Sensitivity to Salt Stress. Plant, Cell and Environment, 26, 595-601. http://dx.doi.org/10.1046/j.1365-3040.2003.00994.x

[36] Yeo, A.R. (1998) Predicting the Interaction between the Effects of Salinity and Climate Change on Crop Plants. Science Horticultural, 78, 159-174. http://dx.doi.org/10.1016/S0304-4238(98)00193-9

[37] Sousa, G.G., Marinho, A.B., Albuqueruqe, A.H.P., Viana, T.V.A. and Azevedo, B.M. (2012) Crescimento inicial do milho sob diferentes concentrações de biofertilizante bovino irrigado com águas salinas. Revista Ciência Agronômica, 43, 237-245. http://dx.doi.org/10.1590/S1806-66902012000200005 
Scientific Research Publishing (SCIRP) is one of the largest Open Access journal publishers. It is currently publishing more than 200 open access, online, peer-reviewed journals covering a wide range of academic disciplines. SCIRP serves the worldwide academic communities and contributes to the progress and application of science with its publication.

Other selected journals from SCIRP are listed as below. Submit your manuscript to us via either submit@scirp.org or Online Submission Portal.
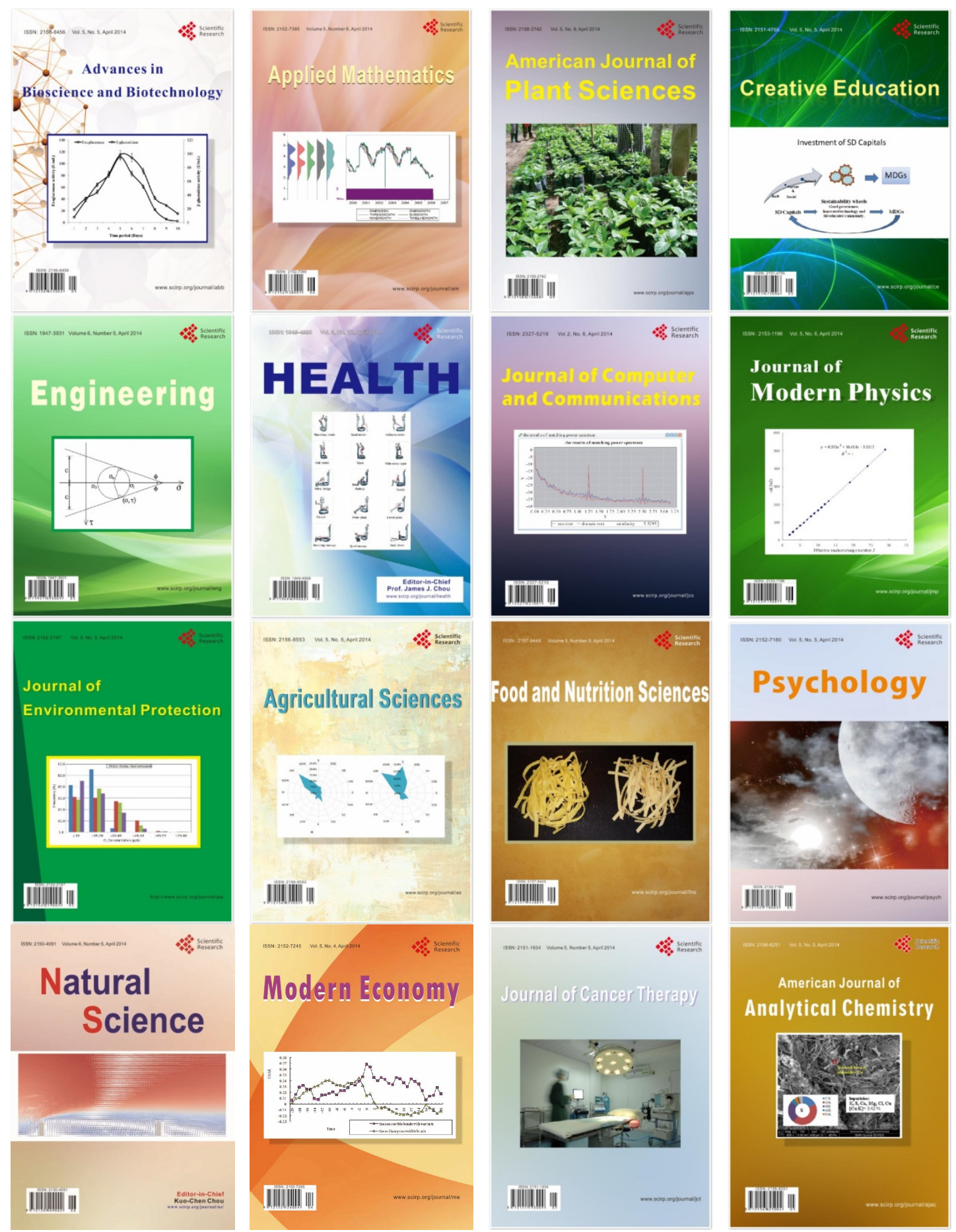